SPIRITUALITY IN NON-VERBAL AUTISM: A SCOPING REVIEW

Towards an Understanding of Spirituality in the Context of Non-verbal Autism: A Scoping Review

This paper represents the first stage of a larger continuing research study, exploring the spirituality of people with non-verbal autism. The purpose of this first stage of the research was to review existing literature on the topic and identify gaps intended to inform the direction(s) of the larger study. Building in the theological construct that all people are "fearfully and wonderfully made" in the divine image of an almighty creator, this research stems from the premise that the lives of all people, including those with profound disability, have purpose and inherent value. Therefore, if Divine intent does underpin "the life context of someone living with a profound disability”, the next logical step in enquiry is to ponder "how a Divine encounter might be experienced by such a person, and how, if at all, would this encounter be expressed by the recipient" [authors]. Deland (1999) proposed that "It may well be that the experiences of people with disabilities will provide not only new images but deeper insight into God's image than those temporarily-abled have ever perceived.” (p. 51). As such the spirituality of people with disabilities is worthy of exploration. The reported increase over the last few decades of the number of people diagnosed with autism, and the particular life context of those with non-verbal autism, who are the least researched and understood people diagnosed with Autism Spectrum Disorder (ASD), formed the impetus for this research.

\title{
Autism Spectrum Disorder
}

The global prevalence of Autism Spectrum Disorders was recently estimated at 1/160 people (Elsabbagh et al., 2012; World Health Organisation [WHO], 2013), or 1\% of the world's population (Lai, Lombardo, \& Baron-Cohen, 2014). It is important to note however that "The prevalence of ASDs in many low- and middle-income countries is as yet unknown" 
SPIRITUALITY IN NON-VERBAL AUTISM: A SCOPING REVIEW

(WHO, 2013, p. 6). Statistics reveal an alarming growth in the diagnosis of autism; in Australia an estimated 115,400 individuals had a diagnosis of ASD in 2012 compared to 64, 400 people in 2009 (Australian Bureau of Statistics [ABS], 2014).

Although there is some argument that the increase in autism could be attributed more to factors such as changing diagnostic criteria, increasing awareness of the disorder, and methodological issues rather than a true increase in cases (e.g., Blumberg et al., 2013; Elsabbagh et al., 2012; Fisch, 2012; Lai et al., 2014), it nevertheless cannot be denied that worldwide statistics reveal an increase in diagnosis (e.g., Baio, 2014; Hertz-Picciotto \& Delwiche, 2009; Parner, Schnedel, \& Thorsen, 2008; Schieve et al., 2012; Zahorodny et al., 2014), and while the cause of this disorder remains hypothesised, there are few people in contemporary society who are not impacted in some way by someone who is diagnosed with ASD.

\section{Autism Defined}

First identified in 1943 by Austrian Psychiatrist Leo Kanner, autism is a complex neurodevelopmental disorder (Ankenman, Elgin, Sullivan, Vincent, \& Bernier, 2014) which recent researchers suggest may result from an interplay of genetic and environmental elements (e.g., Bushnell, 2013; Lasalle, 2013; Siniscalco, Cirillo, Bradstreet, \& Antonucci, 2013).

To date "there is no biological test for ASD” (Kulage, Smaldone, \& Cohn, 2014; Roth, 2013, p. 4), and "diagnosis is based on behavioural [and social] observations” (Roth, 2013, p. 4; Simmons et al., 2009), and parental interviews and questionnaires (Oner, Ozgur, \& Munir, 2014).

The disorder presents with a vast range of idiopathic symptoms in skills typically used for social interaction and communication, and is often characterised by repetitive behaviour (American Psychiatric Association [APA], 2013; Frazier et al., 2014; Malhi \& Singhi, 2014) 
SPIRITUALITY IN NON-VERBAL AUTISM: A SCOPING REVIEW

and narrow and specific interests (Blumberg et al., 2013). Full criteria for diagnosis are outlined in the Diagnostic Statistical Manual of Mental Disorders-5 (DSM-5), a tool commonly used in Australia.

The etiology of ASD can vary widely from person to person and over time (Pasco, 2011; Simmons et al., 2009), and the condition is much more prevalent in males with an estimated ratio between 4:1 (Fombonne, 2009) and 6:1 (Rosti, Sadek, Vaux, \& Gleeson, 2014).

With the introduction of the DSM-5 in May 2013 came a number of major changes to the diagnostic criteria, where various subtypes of the disorder recognised in previous editions of the DSM were replaced by one central diagnosis differentiated by a scale range indicating the level of symptom severity (Giles, 2014; Roth, 2013).

At one end of the autism spectrum are those who identify as 'severe', presenting with limited social engagement, little or no verbal language and often an assumed cognitive disability (McCravy, Johnson, Wetsel, \& Konz, 2010; Persico \& Merelli, 2014).

Traditionally, on the other end of the spectrum are those diagnosed with Asperger Syndrome, who are verbally competent but still demonstrate significant social challenges (Gerhardt, 2003; Pasco, 2011).

As autism is considered a severe disability considerable issues for the family and societal networks of those who are placed on this spectrum are evident. Those with the most severe form of autism, who present as non-verbal and seemingly unable to relate in a way which is recognised and accepted by society are a severely under researched group, manifesting communication and relational barriers that make research more challenging (DeWeerdt, 2013; Whittaker, 2012). Yet the humanness of this group must not be questioned, and as with all human beings, the spiritual element of their existence is worthy of 
SPIRITUALITY IN NON-VERBAL AUTISM: A SCOPING REVIEW

exploration. As such, this literature review focuses on the spirituality of people with nonverbal autism.

\section{Spirituality Defined}

Within any context, seeking to define spirituality has proven problematic. It seems that finding a definition is a fluid process (Barrett, 2011; Beringer, 2000; de Jager Meezenbroek et al., 2012), with the academic literature agreeing only on the point that a “definition of spiritual is not agreed upon (Watson 2001)” (Adams, 2009, p.115). Adams (2009) suggested that because the term spiritual is so resistant to definition, that it is perhaps better described than defined, while Swinton (2001) identified that "spirituality is a slippery concept which is often defined quite differently from context to context” (p.4). For the purpose of this study however, the notion that spirituality is primarily about lived human experience and "inherently oriented towards discovery" (McIntosh, 1998, p.6) is preferred. Spirituality can be thought of as the space where humanity meets the Divine, which inherently makes this space unique, personal and in many ways, undefinable. Theology, the discipline that supports the knowledge and understanding of God and how humans may relate to this Being (Curran, 2010; Erickson, 2013), is intimately related to spirituality (McIntosh, 1998). Yet spirituality is independent in its experiential underpinning, as opposed to the scientific 'knowing' of the discipline of theology.

As this review focuses on the spiritual experiences of those with non-verbal autism, it also aims to explore the possibility of Divine encounter when academic learning (Theology) has not been the foundation for faith. This specific group has been chosen because of the unique human experience within the context of silence and assumed unintelligence that is generally imposed on non-verbal individuals (Geiger, 2012). However, as the daily lives of these people are explored, it can be argued that by their very being, people with non-verbal autism live a life very similar to the mystic or religious dedicate who chooses silence and 
SPIRITUALITY IN NON-VERBAL AUTISM: A SCOPING REVIEW

solitude as a spiritual discipline to encourage and contemplate spiritual mastery. In this context, silence can be defined as "forbearance from speech or noise” or "the state of keeping or being silent” (“Silence”, 2015) and solitude as “the quality or state of being alone or remote from society” (“Solitude”, 2015). Stillman (as cited in Rudy, 2015) proposes “a double standard” that emerges when the life experience of the person who pursues meditation, prayer, silence and other spiritual disciplines in order to achieve a certain "spiritual plateau” (“Question: Is there any research,” para. 2) is viewed alongside the life context of people with non-verbal autism, who generally live in a predominately silent (communication with the absence of words) world (Isanon, 2001). The possibility of a unique, and perhaps even elevated spirituality for this group of people with a specific life experience, opens an interesting opportunity for further exploration. This concept is supported by Isanon (2001) who described people living without conventional language as holding the ability to "stand in silence" having been "stripped of words" (p. 118). He proposed that from the depths of this silence people are able to meet with others at a similar deep and silent place, and a type of listening becomes possible which eventually puts people “perceptively and intuitively in touch with the hearts of others” (p. 118). He further suggested that this type of communication in the silent place becomes transformational, as in the silence of the other we perceive "the mystery of the Incarnation, and come to know it as our own” (p.119). Isanon (2001) claimed that the person living without conventional language possesses a "spiritual wealth" which has the ability to lead others to their own spirituality through their meeting at this internal silent place (p. 119).

There appears to be no existing scoping or systematic literature review on the spirituality of those with non-verbal autism. As such a rigorous search of the limited available peer-reviewed literature was conducted in order to discover what is already known 
SPIRITUALITY IN NON-VERBAL AUTISM: A SCOPING REVIEW

and documented about the spiritual expressions and experiences of people with autism, specifically those with non-verbal autism.

\section{Research Questions}

The overriding research question for this scoping literature review has been formulated as follows:

1. What are the spiritual experiences of people with non-verbal autism? The second research question evolved as a natural consequence of the above exploration and is as follows:

2. What can be learned from the spiritual experiences of people with non-verbal autism?

Consideration of how to find the answer to these questions formed further questions as part of this review. A theological exploration of the importance of every person as a valued member of the Church, and indeed the Church's responsibility to respond to and include all people leads to the third question.

3. What are the implications of the findings of this research for Faith Communities and other service providers?

When considering the scope of this particular scoping literature review, a fourth question must be considered and addressed as follows:

4. What should be the direction of further research on the spiritual experiences and expressions of people with non-verbal autism?

\section{Methodology}

A scoping literature review methodology was considered most appropriate for this research for the following two reasons: a) it is very difficult to conduct qualitative research on non-verbal individuals due to the inherent communication barriers, and b) relating to this, 
SPIRITUALITY IN NON-VERBAL AUTISM: A SCOPING REVIEW

the lack of clinical trials involving non-verbal individuals means that an alternative systematic literature based methodology such as a meta-analysis is not possible.

A scoping literature review is an investigation based on a specific question(s) and typically involves rigorous and comprehensive searches of available literature on a chosen topic (Halas et al., 2015). Relevant literature is then synthesised and key concepts and research gaps identified (Halas et al., 2015).

Although sharing many qualities such as a systematic approach, what distinguishes a scoping from a 'systematic' literature review is that a scoping review does not assess the methodological quality of the gathered literature (Grant \& Booth, 2009). Rather, a scoping review "aims to identify the nature and extent of research evidence" available on the chosen topic thereby indicating whether more extensive research is necessary (Grant \& Booth, 2009, p. 101). As a systematic review aims to provide answers "from a relatively narrow range of quality assessed studies” (Arksey \& O’Malley, 2005, p. 20), it emerged in this study that a scoping literature review would be a more appropriate methodology given the negligible academic literature dedicated to the topic.

\section{Method}

As a first step to this review an initial thorough search of peer reviewed academic literature (including theses and dissertations) was conducted. All searches were conducted from 2013 - 2015, however the papers sourced were not necessarily published during this period. The literature was selected based on the inclusion/exclusion criteria presented in Table 1.

[Please insert Table 1 about here]

\section{Search Methods}

To obtain the most comprehensive range of literature the search consisted of five phases. In Phases One-Three of the search 14 electronic academic databases were searched. 
Simultaneously, to minimise the risk of failing to locate relevant literature, a thorough hand search through the archives of 11 journals was made, all of which provided online access to all issues. These are presented in Table 2.

[Please insert Table 2 about here]

Subsequently, search alerts were set up with Journal of Autism and Developmental Disorders, Review Journal of Autism and Developmental Disorders, Journal of Intellectual \& Developmental Disability, Journal of Non-verbal Behavior, International Journal for Philosophy of Religion, Communication Disorders Quarterly, and the American Association on Intellectual and Developmental Disabilities, to indicate when new issues were available. These journals were chosen because of the regular publications relevant to the topic they offer. Finally, additional articles were identified and selected from the reference lists of retrieved articles.

All searches were Boolean searches which were sorted within each database (wherever possible) by relevance or "best match" to the key word search terms used. Search terms for each phase are presented in Table 3.

[Please insert Table 3 about here]

\section{Assessment of Relevance}

Relevance, based on inclusion criteria, was assessed in two stages for all search Phases. Firstly, a cursory scan of the title, abstract and introduction of each article/theses/dissertation was conducted. This was to determine the context in which the key word search terms were used and the frequency in which they were mentioned. It was found that some abstracts and titles were of little relevance and these were excluded. During the second assessment the full text of the remaining literature was independently reviewed by two people and assessed for: a) the applicability to the review questions, b) relevance or 
SPIRITUALITY IN NON-VERBAL AUTISM: A SCOPING REVIEW

presence of identified gaps relevant to the topic, c) the goal/focus/relevant arguments, and d) the extent to which relevant concepts were discussed.

Methodological weaknesses were noted during the second stage of assessment however the available literature specific to the topic was limited. The majority of the literature, particularly that of a theological nature, was theoretical. It is acknowledged that there is limited academic research in this area, therefore, in order to adequately scope and explore what is known in this field, it became necessary to include both research literature and conceptual/theoretical works for examination.

The selected literature was each tabled according to the degree of relevance to the review (high, moderate, and limited) as determined in the assessment, and then categorised into the appropriate topics (See Table 4 for an example).

[Please insert Table 4 about here]

\section{Search Phases}

\section{Search Phase One: Theology of disability.}

This phase focused specifically on the Theology of Disability literature. Using the key word search terms presented in Table 3, the purpose of this search was to discover what the literature reveals about people with non-verbal autism from a theological viewpoint. It was also the intention of this search to explore what were the current attitudes and beliefs within faith communities about people with disabilities generally and autism specifically. This search realised a large number of hits (830), but by using the nominated exclusion criteria these were narrowed down firstly to 234 and from these 107 were selected that were considered most relevant to the topic.

\section{Search Phase Two: Theology and spirituality.}

The purpose of Phase Two was to clarify the difference between theology and spirituality, and to explore the Theology of Spirituality. This search realised a total of 2,834 
papers. Using the same exclusion criteria, from these a total of 38 papers deemed most relevant were tabled in the same manner as in Phase One.

Simultaneously, in seeking to gain some insight into the process and experience gained by the spiritual discipline of silence and contemplation, the topic of mysticism was also searched. This search found a total of 1,079 papers. From these 23 papers were selected, which were then sorted and categorised. This literature revealed a wealth of information about the process and benefit of silence when used as a spiritual discipline.

\section{Search Phase Three: Spirituality of disability.}

This search focused on the spirituality of disability, in particular autism, and realised a large number of 'hits' $(14,648)$, which were then narrowed down to 85 papers when the inclusion/exclusion criteria were applied. These were then assessed as in previous Phases, leaving a total of 67 papers that were considered to be most relevant to the review. As the literature collected from this search was reviewed and categorised, a pattern of recurring themes emerged (see Table 5).

[Please insert Table 5 about here]

\section{Search Phase Four: Alternate literature.}

Although the original aim of the review was to inspect the academic literature it became overwhelmingly clear that very little empirical research exists that specifically considers the spiritual experiences, needs or wants, giftedness or unique offerings of people with intellectual or developmental disabilities generally (see Geiger, 2012 for a rare example), and people with non-verbal autism specifically. This lack of research may in part be due to the challenges of researching people when the nature of their communication difficulties means that data collection relies primarily on parental and carer perspectives and observation (e.g., see Geiger, 2012). 
SPIRITUALITY IN NON-VERBAL AUTISM: A SCOPING REVIEW

This discovery prompted a broadening of the scope of the review to include other genres such as the biographies and autobiographies of people with non-verbal autism. While limited in number these sources provided a rich source of data specific to the review questions.

Mostly these works have been recorded using some form of augmentative or assisted communication, which is a controversial means of providing assistance to non-verbal persons by the use of innovations such as a keyboard or alphabet facsimile (Schlosser et al., 2014). Originally initiated in Australia in the 1970's by health provider Rosemary Crossley (Travers, Tincani, \& Lang, 2014), globally facilitated communication is still viewed with some suspicion. The use of a second person (the facilitator) to facilitate the process for people who lack the bodily stability to type unassisted (Schlosser et al., 2014) is viewed by some as suspect. Ongoing research continues to debate the authenticity of facilitated communication, with evidence which both supports (e.g., Cardinal \& Falvey, 2014; Rosetti, Ashby, Arndt, Chadwick, \& Kasahara, 2008) and discounts the credibility of the method (e.g., Schlosser et al., 2014; Travers et al., 2014). Even so, the use of various types of these innovations is gaining wider respect within academic and medical communities (Cardinal \& Falvey, 2014). What cannot be denied is the experience of people with non-verbal conditions who report a resounding experience of freedom when provided the means, often for the first time ever, to communicate in a meaningful way, "deflating the notion that not being able to speak means having nothing to say” (Grandin, 2011, p.110).

A broad search of Amazon and Google books for literature on non-verbal autism produced over 450,000 results. After applying the below search exclusion criteria this was reduced to 47 relevant books. These include books by specialists such as William Stillman, whose works explore Spirituality and autism from a phenomenological perspective; also Temple Grandin, Olga Bogdashina, Digby Tantam, Amos Yong, John Gillibrand, and 
Colleen Swindoll Thompson. Other books included 21 autobiographies written by people with non-verbal autism with the assistance of their parent(s). A small number of books written by parents have also proven a valuable source of data. The majority of these books describe in some way the unique spiritual experiences of the author. As in Search Phases One-Three these books were assessed and categorised according to their topic and relevance to the review questions. Detailed information from these books was entered into an Excel database and included, but was not limited to that detailed in Table 6.

[Please insert Table 6 about here]

Exclusion criteria for books was: Books published in languages other than English, books written for children or adolescents, parental reflections on living with a child with autism, resource books for teachers, doctors, specialists and related professions, books written by individuals who have always been verbal, and books describing treatments and/or symptoms. As in previous Phases relevance was assessed by a scan of the book abstract and, if available, Table of contents and a preview of chapters.

Importantly, it became apparent that the small number of biographical works written predominately by people with non-verbal autism by means of facilitated communication, or their parent/carer, provided such a valuable contribution to the review that it was an important representation of information that was otherwise unavailable in its own right, and deserving of a distinct representative category identifying it as such. This group of works was titled "Non-verbal Narratives", to honour the group of unique people it represented. Each book within this genre was written either by or in conjunction with someone with nonverbal autism. See Table 7 for a list of relevant books.

[Please insert Table 7 about here] 
SPIRITUALITY IN NON-VERBAL AUTISM: A SCOPING REVIEW

Furthermore, without exception, each work revealed significant discoveries relevant to this review when a person lacking speech finally found a means for communication (Table 8 details some relevant themes).

[Please insert Table 8 about here]

\section{Search Phase Five: Social multimedia.}

Finally, once it became clear that there existed a body of work that could provide valuable information for this review, it was decided that an exploration of a wider scope of similar non-academic resources would be prudent. An internet search was conducted to locate social multimedia relevant to the review, with a focus on non-verbal individuals with autism. This included a search of Google for internet sites and blogs, as well as a search of Facebook and YouTube all of which proved to be a small, but very rich source of data specific to the review questions. From this initial search, the most useful of these to the review are presented in Table 9. For the purposes of this review these media resources became a subcategory within the Non-verbal Narrative genre entitled "Internet and Social Media Narrative”.

[Please insert Table 9 about here]

\section{Results and Discussion}

This review identified several themes from the available academic literature relevant to the review questions. Firstly, it became evident from the literature that as disability theologians and faith communities wrestle with the ethical and organisational responses concerning contemporary social attitudes of equality and inclusion for people with disabilities, new perspectives are emerging that are being personally and empirically confronted. It also became evident that most of the literature seems to focus on issues of inclusion into existing community or religious settings, rather than a first person account of the spirituality of people with non-verbal autism. These findings are presented in Table 10. 
SPIRITUALITY IN NON-VERBAL AUTISM: A SCOPING REVIEW

[Please insert Table 10 about here]

It is encouraging to note that within some faith communities, at last there is some attention being paid to the various needs of specific members. Along with initiatives for inclusion in worship and social activities there is also some momentum in the consideration of modified confirmation curriculums (Kramer-Mills, 2010), and basic scripture lessons and catechism classes which have been specifically designed for children with autism and other learning needs (Vogel \& Reiter, 2003; Webster, 2004; Weerstra, 2011). These types of specialist considerations are valuable and necessary, not only for the individual, but also the growth and function of the faith community as a whole (Brock, 2011; Greig, 2015; McGee, 2010; McNair, 2008; Reynolds, 2012). Secondly, there appears to be a lot of room in future research to consider the response of these institutions to the individual with a disability, and specifically those with autism. There is little research available that explores how these people can integrate into their local religious community and participate as valued members of the fold (Webb-Mitchell, 2010). People with non-verbal autism invite a unique type of consideration in terms of communication and fellowship (Kramer-Mills, 2010), and while these obstacles may prove difficult to address, they must be considered within their own unique context of Disability Theology. Thirdly, and further to this identification, there was no evidence in this literature of any reference specifically referring to the unique spiritual experiences the person with autism may encounter as they connect to the Divine within their own life journey, or how this experience may then be expressed within their own life context. Nor was there any mention of any kind in the academic literature concerning the theology or spirituality of people with non-verbal autism from their individual perspective.

A number of obvious gaps have also been revealed. At a grass roots level, although it seems to be a growing field of interest it appears that little information is available regarding the role of spirituality or religion in the lives of individuals with disabilities, and this gap is 
SPIRITUALITY IN NON-VERBAL AUTISM: A SCOPING REVIEW

even further exaggerated in regards to those who are non-verbal (e.g., Dubin \& Graetz, 2009; Geiger, 2012; McGrath \& Newell, 2004; Russinova \& Cash, 2007; Samuel, 2009; SchaapJonker, Sizoo, van Schothorst-van Roekel, \& Corveleyn, 2013; Selway \& Ashman,1998; Shogren \& Rye, 2008; Speraw, 2006; Swinton, 2011; Swinton \& Trevett, 2009; Turner, Hatton, Shah, Stansfield, \& Rahim, 2004; Visuri, 2012; Vogel \& Reiter, 2003; Zhang \& Rusch, 2005). It has also been noted by several researchers (e.g., Ault, Collins, \& Carter, 2013; Speraw, 2006; Swinton \& Trevett, 2009; Zhang \& Rusch, 2005) that to date few studies (see Geiger, 2012; Schaap-Jonker et al., 2013; Shogren \& Rye, 2008; Turner et al., 2004; Visuri, 2012 for examples) have investigated the spiritual or religious views or understandings of people with any type of developmental or intellectual disability, and in the wider scope of care and treatment for people with intellectual disabilities this gap in the literature is identified as well.

Another gap this search exposed (noted by researchers such as Selway \& Ashman, 1998) is the limited research that investigates the range and forms of spirituality and religion or personal experiences of spirituality in people with disabilities, especially those with autism or other non-neurotypical disorders (see Geiger, 2012; Shogren \& Rye, 2008; Swinton \& Trevett, 2009; Turner et al., 2004; Visuri, 2012; Vogel \& Reiter, 2003 for examples). See Table 11 for a summary of gaps in the literature.

[Please insert Table 11 about here]

Given that the academic literature on the topic is scant, as this review progressed it became clear that the genre of literature titled "Non-verbal Narratives" is vital to the understanding of the spiritual experiences of people with non-verbal autism for a number of reasons. Firstly and significantly, to date there appears to be no available academic literature that has specifically explored spirituality from the experiential viewpoint of anyone without specific use of language as these sources do. Secondly, this is such a unique topic that this 
omission is rarely even acknowledged in the academic literature. One of the few papers which does identify this gap is by Liu and colleagues (2014), who concluded in their study of the spiritual experiences of individuals with intellectual disabilities, that "creative approaches are needed to discern the perspectives and practices of individuals who cannot speak, but still have something important to say about this area of their lives” (p. 400). However they suggested that this could best be done by observational research and interviews with carers and family members rather than by obtaining information directly from a non-verbal individual. Furthermore, it has only been in recent years that the personal journeys of nonverbal individuals have been able to be communicated in language that is understandable to others, providing direct access to previously elusive information about the life experience of this group. This is largely due to the growing acceptance and wider use of various forms of assisted communication (Geiger, 2012) which was used by the authors of the Non-verbal Narrative literature. Most importantly however, is the fact that this genre is a rich source of personal experience, most often written in the first person by someone who is living the experience of a non-verbal life, or alternatively by someone very close to them. Therefore, it was determined that this genre of literature is likely the best, and only, known source of information available.

The term "Non-verbal Narratives" is intended to characterise and make alive the unique life experience of people who are unable to use conventional language, but nevertheless have a valuable story to tell. It is intended that the action of shaping the life context of this group of people into an identifiable term will assist to normalise their experience, and as such contribute to wider acceptance and respect for them, and also contribute to a wider understanding of human spirituality. This term is intended to introduce an alternative understanding of difference rather than a negative or deficit approach to empirical research. Therefore, the experiences and expressions of people without 
SPIRITUALITY IN NON-VERBAL AUTISM: A SCOPING REVIEW

conventional language should be viewed as having intrinsic value in and of themselves (Stillman, 2006), and although the available resources for sourcing this data may not be conventional, they should not be discounted as invalid. For instance, prior research has argued for the value of narrative (e.g., Kokanovic \& Stone, 2010; Sunderland, Chenoweth, Matthews, \& Ellem, 2015) and autobiographical data (e.g., Haynes, 2006; Williams, 2004; Zhang \& Rusch, 2005) as a "rich resource" (Haynes, 2006, p. 400) that is able to "prise open the different dimensions of lived totality” (Gottfried, 1998, p. 452). It has been variously used in "social science, accounting, and feminist research” offering “an opportunity for new insights” (Haynes, 2006, pp. 403, 415). More recently Dahl (2009) has argued for a revised approach to non-academic sources such as internet sources and social media as a valid source of information although she urges caution, recommending that these sources must be of relevance, legitimate, and add value to the research. Therefore, the inclusion of the alternative genre of literature titled "Non-verbal Narrative" is justified as a valuable source of information that contextualises research into this group.

The purpose of this scoping review is to discover the unique spiritual expressions of people with non-verbal autism. This group provides the unique opportunity to explore the spirituality of people who are less exposed to societal and religious traditions through normative language and religious discourse. Therefore, the data collected within the "Nonverbal Narrative” genre is seen as pure in that it has not been contaminated by societal and religious norms. In this way, this research could be argued to have similarities with some of the documented discoveries of 'uncontacted' tribal groups who have existed in remote locations. These primitive groups are prized by researchers due to the invaluable and rare glimpses into an untouched society where they have "kept their primeval innocence” and "bear witness to a remarkable culture” (Riefenstahl as cited in Ludewig, 2006, pp. 87, 89). In being granted an opportunity to communicate, those with non-verbal autism are now able to 
SPIRITUALITY IN NON-VERBAL AUTISM: A SCOPING REVIEW

share previously inaccessible information akin to the sharing of information when these tribal groups are first contacted.

In terms of the spiritual experiences and expressions of people with non-verbal autism, the academic literature appears to only provide gaps that offer opportunities for further exploration. In an attempt to bridge those gaps future research therefore must use what literature is available to secure the data that will forward this process. This includes the Non-verbal Narrative literature.

\section{Implications}

The implications for this research are wide reaching, although are not without significant challenges in implementation. In contemporary society, consideration of the inner experience of any people group is no longer the sole responsibility of faith communities. Research indicates that spirituality is fundamental to the provision of holistic care and services in professions such as education, (Adams, Bull, \& Maynes, 2015; Campbell, 2009, 2011), nursing (Buckle, 1993; Nixon, Narayanasamy, \& Penny, 2013), occupational and speech-language therapy (Gray, 2015; Mathisen et al., 2015), social work (Crisp, 2008), and disability carer roles (Baldwin et al., 2015; Wilson, 2011). This study reveals that the inner world and life experience of those with non-verbal autism is unexplored from an empirical point of view, which reveals serious concerns about the ability of service providers to adequately understand and advocate appropriately for people with this unique life context. Contemporary research is leading the way for changes in approaches to education for children with autism (Crosland \& Dunlap, 2012; Young-Pelton \& Doty, 2013), however for the non-verbal child research is mostly limited to initiatives designed to promote speech (e.g., Gordon et al., 2011; Lepper, Petursdottir, \& Esch, 2013; Sandiford, Mainess, \& Daher, 2013).

The ability of professionals and family members to embrace and work with difference is imperative to the functioning, growth and wellbeing of those with different life contexts. 
Initial exploration of relevant data as outlined in this study reveals that contrary to contemporary understanding and ideation concerning people with non-verbal autism, these people seem to possess unique and seemingly superior giftedness in many areas (Bogdashina, 2013; Grandin, 2011; Stillman, 2006). By exploring the available literature presented in this review in the non-verbal narrative genre, a profound intelligence and personal awareness is increasingly evidenced in people with non-verbal autism.

This discovery provides opportunities for further research across a number of disciplines. Underpinning any service to people with non-verbal autism with the acknowledgement of their inherit intelligence affords the possibility of enhanced life experience on many levels. This experience includes autonomy, informed consent, opportunities for socialisation, enhanced creative expression, personal lifestyle choices and individual input into the development of more effective and personalised communication devices just to name a few. Changes in educational strategies and policy are suggested as a starting point for embracing individual potential for learning and growth. Other on-going considerations include those concerning healthcare, disability services, parent and caregiver awareness, individual autonomy and life skills training, and financial implications amongst many others.

There are also serious implications for faith communities to consider in terms of the place afforded to people with different life contexts and needs within communities. Further research concerning the spiritual experiences and expressions of people with non-verbal autism is continuing as a result of the findings of this literature review. How the findings of this research impacts faith communities in their inclusion of people with non-verbal autism is yet to be discovered. Beyond inclusion, the possibility must also be considered that these people can and will enrich faith communities as they offer their own unique spiritual insights (Stillman, 2006), a valuable implication that must not be ignored. 


\section{Conclusion}

\section{Limitations}

This review has several limitations which should be acknowledged. Firstly, it was only possible to include sources which were either written in, or translated into the English language. Whilst this literature provided a comprehensive collection it is possible that the exclusion of non-English language material may mean that there are important sources which are not included in the review. Further, some articles and theses/dissertations which may have been of relevance were unable to be obtained in full text due to financial constraints. Choice of key words may mean that the searches did not identify all possible academic literature on the topic. However, an extensive range of search terms and comprehensive number of available databases were used in an attempt to minimize this issue. Finally, time constraints meant that it is possible that there are more recent publications not included in this review. Equally problematic, the number of 'hits' in YouTube and Google made it impossible to conduct a rigorous search due to time constraints.

\section{Further Research}

Despite these limitations, this scoping review identified a significant gap in the available academic literature on the spirituality of individuals with non-verbal autism. Opportunities for further research became apparent during the course of conducting this review including an in-depth exploration of the 'Non-verbal Narrative' literature, specifically that authored by individuals with non-verbal autism or their parent/carer. Valuable data can also be found in a scant amount of works by non-academic professionals in the field who have a specific interest in the life context of people with non-verbal autism. Additionally, it was recognised that conducting interviews with people with non-verbal autism via the use of assisted communication will assist to validate data sourced from the non-verbal narrative literature, and to also identify key elements which may not be documented in the literature. 
SPIRITUALITY IN NON-VERBAL AUTISM: A SCOPING REVIEW

The identification of this research gap and these two opportunities for further investigation directed the development of a larger research study which is currently underway. 
SPIRITUALITY IN NON-VERBAL AUTISM: A SCOPING REVIEW

\section{References}

Adams, K. (2009). The rise of the child's voice; the silencing of the spiritual voice. Journal of Beliefs \& Values: Studies in Religion \& Education, 30, 113-122. doi: 10.1080/13617670903174991

Adams, K., Bull, R., \& Maynes, M. (2015). Early childhood spirituality in education: Towards an understanding of the distinctive features of young children's spirituality. European Early Childhood Education Research Journal, 1-15. doi: 10.1080/1350293X.2014.996425

American Psychiatric Association. (2013). Diagnostic and statistical manual of mental disorders. Fifth edition (DSM-5). Washington, DC: Author.

Ankenman, K., Elgin, J., Sullivan, K., Vincent, L., \& Bernier, R. (2014). Nonverbal and verbal cognitive discrepancy profiles in autism spectrum disorders: Influence of age and gender. American Journal on Intellectual and Developmental Disabilities, 119, 84-99. doi: 10.1352/1944-7558-119.1.84

Arksey, H., \& O’Malley, L. (2005). Scoping studies: Towards a methodological framework. International Journal of Social Research Methodology, 8, 19-32. doi: 10.1080/1364557032000119616

Ault, M., Collins, B., \& Carter, E. (2013). Factors associated with participation in faith communities for individuals with developmental disabilities and their families. Journal of Religion, Disability \& Health, 17, 184-211.

doi: 10.1080/15228967.2013.781777

Australian Bureau of Statistics. (2014). Autism in Australia, 2012 (Cat. No. 4428.0). Retrieved from http://www.abs.gov.au/

Baio, J. (2014). Prevalence of autism spectrum disorder among children aged 8 yearsAutism and Developmental Disabilities Monitoring Network, 11 Sites, United States, 
SPIRITUALITY IN NON-VERBAL AUTISM: A SCOPING REVIEW

2010. Morbidity and Mortality Weekly Report, 63, 1-21. Retrieved from http://www.cdc.gov

Baldwin, P.J., Evans, J., Etherington, N., Nichols, M., Wright, V., \& McDougall, J. (2015). Youth with disabilities talk about spirituality: A qualitative descriptive study. The Qualitative Report, 20, 941-958. Retrieved from http://nsuworks.nova.edu/

Barrett, N. (2011). Wuwei and flow: Comparative reflections on spirituality, transcendence, and skill in the Zhuangzi. Philosophy East \& West, 61, 679-706. doi: 10.1353/pew.2011.0051

Bennett, T., Deluca, D., \& Allen, R. (1995). Religion and children with disabilities. Journal of Religion and Health, 34, 301-312. doi: 10.1007/BF02248739

Beringer, A. (2000). In search of the sacred: A conceptual analysis of spirituality. Journal of Experiential Education, 23, 157-165. doi: 10.1177/105382590002300307

Blumberg, S., Bramlett, M., Kogan, M., Schieve, L., Jones, J., \& Lu, M. (2013). Changes in prevalence of parent-reported autism spectrum disorder in school-aged US children: 2007 to 2011-2012 (National Health Statistics Reports No. 65). Retrieved from U.S. Department of Health and Human Services Centers for Disease Control and Prevention website: http://www.cdc.gov/

Bogdashina, O. (2013). Autism and spirituality. London, England: Jessica Kingsley. Brock, B. (2009). Autism, care and Christian hope. Journal of Religion, Disability \& Health, 13, 7-28. doi: 10.1080/15228960802581404

Brock, B. (2011). Theologizing inclusion: 1 Corinthians 12 and the politics of the body of Christ. Journal of Religion, Disability \& Health, 15, 351-376. doi: 10.1080/15228967.2011.620389

Buckle, J. (1993). When is holism not complementary? British Journal of Nursing, 2, 744745. Retrieved from http://www.ncbi.nlm.nih.gov/pubmed 
SPIRITUALITY IN NON-VERBAL AUTISM: A SCOPING REVIEW

Bushnell, P.J. (2013). Special issue: Environmental influences and emerging mechanisms in the etiology of autism. Neurotoxicology and Teratology, 36, 1-2. doi:10.1016/j.ntt.2013.03.001

Campbell, L.H. (2009). Spirituality in holistic art education: Preventing violence among youth in the United States. Journal of Cultural Research in Art Education, 27, 122131. Retrieved from http://www.proquest.com

Campbell, L.H. (2011). Holistic art education: A transformative approach to teaching art. Art Education, 64, 18-24. Retrieved from http://www.proquest.com

Cardinal, D.N., \& Falvey, M.A. (2014). The maturing of facilitated communication: A means toward independent communication. Research and Practice for Persons with Severe Disabilities, 39, 189-194. doi: 10.1177/1540796914555581

Conner, B. T. (2010). Affirming presence: Spiritual life and friendship with adolescents with developmental disabilities. International Journal of Children's Spirituality, 15, 331-339. doi: 10.1080/1364436X.2010.533479

Crisp, B.R. (2008). Social work and spirituality in a secular society. Journal of Social Work, 8, 363-375. doi: 10.1177/1468017308094990

Crosland, K., \& Dunlap, G. (2012). Effective strategies for the inclusion of children with autism in general education classrooms. Behavior Modification, 36, 251-269. doi: $10.1177 / 0145445512442682$

Curran, I. (2010). Theology as a spiritual discipline. Liturgy, 26(1), 3-10. doi: 10.1080/0458063X.2010.519610

Dahl, C. (2009). Undergraduate research in the public domain: The evaluation of nonacademic sources online. Reference Services Review, 37, 155-163. doi: 10.1108/00907320910957198

Dearey, P. (2009). Do the autistic have a prayer? Journal of Religion, Disability \& Health, 
SPIRITUALITY IN NON-VERBAL AUTISM: A SCOPING REVIEW

13, 40-50. doi: 10.1080/15228960802581420

Deeley, Q. (2009). Cognitive style, spirituality, and religious understanding: The case of autism. Journal of Religion, Disability \& Health, 13, 77-82.

doi: 10.1080/15228960802581479

de Jager Meezenbroek, E., Garssen, B., van den Berg, M., van Dierendonck, D., Visser, A., \& Schaufeli, W. (2012). Measuring spirituality as a universal human experience: A review of spirituality questionnaires. Journal of Religion \& Health, 51, 336-354. doi: 10.1007/s10943-010-9376-1

Deland, J. (1999). Images of God through the lens of disability. Journal of Religion, Disability \& Health, 3, 47-81. doi: 10.1300/J095v03n02_06

DeWeerdt, S. (2013, September 2). Study of nonverbal autism must go beyond words, experts say. Spectrum. Retrieved from http://sfari.org/news-andopinion/news/2013/study-of-nonverbal-autism-must-go-beyond-words-experts-say

Dubin, N., \& Graetz, J. (2009). Through a different lens: Spirituality in the lives of individuals with Asperger's syndrome. Journal of Religion, Disability \& Health, 123, 29-39. doi: 10.1080/15228960802505213

Elsabbagh, M., Divan, G., Koh, Y.J., Kim, Y.S., Kauchali, S., Marcin, C,...Fombonne, E. (2012). Global prevalence of autism and other pervasive developmental disorders. Autism Research, 5, 160-179. doi: 10.1002/aur.239

Emmons, R. (2005). Striving for the sacred: Personal goals, life meaning and religion. Journal of Social Issues, 61, 731-745. doi: 10.1111/j.1540-4560.2005.00429.x

Erickson, M. (2013). Christian theology (3rd ed.). Grand Rapids, MI: Baker Academic. Fisch, G.S. (2012). Nosology and epidemiology in autism: Classification counts. American Journal of Medical Genetics Part C: Seminars in Medical Genetics, 160C, 91-103. doi: 10.1002/ajmg.c.31325

Fombonne, E. (2009). Epidemiology of pervasive developmental disorders. Pediatric 
SPIRITUALITY IN NON-VERBAL AUTISM: A SCOPING REVIEW

Research, 65, 591-598. doi: 10.1203/PDR.0b013e31819e7203

Frazier, T.W., Thompson, L., Youngstrom, E.A., Law, P., Hardan, A.Y., Eng, C., \& Morris, N. (2014). A twin study of heritable and shared environmental contributions to autism. Journal of Autism and Developmental Disorders, 44, 2013-2025. doi: $10.1007 / \mathrm{s} 10803-014-2081-2$

Geiger, M. (2012). Through the eyes of children: Theological lessons with and from children with severe communication disabilities. Journal of Religion, Disability \& Health, 16, 102-113. doi: 10.1080/15228967.2012.645615

Gerhardt, P.F. (2003). Transition support for learners with Asperger syndrome. In R.W. DuCharme \& T. P. Gullotta (Eds.), Issues in children's and families’ lives: Vol. 3. Asperger syndrome. A guide for professionals and families (pp. 157-171). New York, NY: Springer.

Giles, D.C. (2014). 'DSM-V is taking away our identity': The reaction of the online community to the proposed changes in the diagnosis of Asperger's disorder. Health: An Interdisciplinary Journal for the Social Study of Health, Illness and Medicine, 18, 179-195. doi: 10.1177/1363459313488006.

Gordon, J. (2009). Is a sense of self essential to spirituality? Journal of Religion, Disability \& Health, 13, 51-63. doi: 10.1080/15228960802581438

Gordon, K., Pasco, G., McElduff, F., Wade, A., Howlin, P., \& Charman, T. (2011). A communication-based intervention for nonverbal children with autism: What changes? Who benefits? Journal of Consulting and Clinical Psychology, 79, 447457. doi: $10.1037 / \mathrm{a} 0024379$

Gottfried, H. (1998). Beyond patriarchy: Theorising gender and class. Sociology, 32, 451468. doi: 10.1177/0038038598032003003

Grandin, T. (2011). The way I see it. A personal look at Autism and Asperger's (2nd 
SPIRITUALITY IN NON-VERBAL AUTISM: A SCOPING REVIEW

ed.). Arlington, TX: Future Horizons.

Grant, M.J., \& Booth, A. (2009). A typology of reviews: An analysis of 14 review types and associated methodologies. Health Information and Libraries Journal, 26, 91-108. doi: 10.1111/j.1471-1842.2009.00848.x

Gray, G. (2015). Spirituality and occupational therapy. Journal of the National Society of Allied Health, 12, 53-62. Retrieved from http://www.proquest.com

Greig, J.R. (2015). “Let the children (with Down Syndrome) come to me”: God’s Shalom and the radical hospitality of the Church. Journal of Disability \& Religion, 19, 5065. doi: 10.1080/23312521.2015.992618

Halas, G., Schultz, A.S.H., Rothney, J., Goertzen, L., Wener, P., \& Katz, A. (2015). A scoping review protocol to map the research foci trends in tobacco control over the last decade. BMJ Open, 5, e006643. doi:10.1136/bmjopen-2014-006643

Haynes, K. (2006). Linking narrative and identity construction: Using autobiography in accounting research. Critical Perspectives on Accounting, 17, 399-418. doi: 10.1016/j.cpa.2004.08.005

Hertz-Picciotto, I., \& Delwiche, L. (2009). The rise in autism and the role of age at diagnosis. Epidemiology, 20, 84-90. doi: 10.1097/EDE.0b013e3181902d15

Huels, J. (1984). “Use of reason” and reception of sacraments by the mentally handicapped. The Jurist, 41, 209-219. Retrieved from http://cuapress.cua.edu/journals/jurist.cfm

Hurlbutt, K., \& Chalmers, L. (2002). Adults with autism speak out: Perceptions of their life experiences. Focus on Autism and Other Developmental Disabilities, 17, 103-111. doi: $10.1177 / 10883576020170020501$

Hyman, M. (2009). Standing at Sinai with autism. A young man’s Bar Mitzvah journey. Journal of Positive Behavior Interventions, 11, 186-192.

doi: $10.1177 / 1098300708329012$ 
SPIRITUALITY IN NON-VERBAL AUTISM: A SCOPING REVIEW

Isanon, A. (2001). Spirituality and the autism spectrum. Of falling sparrows. London, England: Jessica Kingsley.

Jacober, A. (2010). Youth ministry, religious education, and adolescents with disabilities: Insights from parents and guardians. Journal of Religion, Disability \& Health, 14, 167-181. doi: 10.1080/15228961003622310

Kaye, J., \& Raghavan, S. (2002). Spirituality in disability and illness. Journal of Religion \& Health, 41, 231-242. doi: 10.1023/A:1020284819593

Kleinert, H., Sharrard, D., Vallance, M., Ricketts, E., \& Farley, J. (2010). Teaching seminary students about faith inclusion for individuals with developmental disabilities: The role of family mentorships. Journal of Religion, Disability \& Health, 14, 6-27. doi: 10.1080/15228960903517299

Kokanovic, R., \& Stone, M. (2010). Doctors and other dangers: Bosnian refugee narratives of suffering and survival in Western Australia. Social Theory \& Health, 8, 350-369. doi: $10.1057 /$ sth.2010.10

Kramer-Mills, H. (2010). Walter’s ingress: How a young man transformed a church. Journal of Religion, Disability \& Health, 14, 267-278.

doi: 10.1080/15228961003622344

Kulage, K.M., Smaldone, A.M., \& Cohn, E.G. (2014). How will DSM-5 affect autism diagnosis? A systematic literature review and meta-analysis. Journal of Autism and Developmental Disorders, 44, 1918-1932. doi: 10.1007/s10803-014-2065-2

Lai, M-C., Lombardo, M.V., \& Baron-Cohen. (2014). Autism. The Lancet, 383, 896910. doi: 10.1016/S0140-6736(13)61539-1

Lasalle, J.M. (2013). Epigenomic strategies at the interface of genetic and environmental risk factors for autism. Journal of Human Genetics, 58, 396401. doi: 10.1038/jhg.2013.49. 
SPIRITUALITY IN NON-VERBAL AUTISM: A SCOPING REVIEW

Lepper, T.L., Petursdottir, A.I., \& Esch, B.E. (2013). Effects of operant discrimination training on the vocalizations of nonverbal children with autism. Journal of Applied Behavior Analysis, 46, 656-661. doi: 10.1002/jaba.55

Lewis, A. (2009). Methodological issues in exploring the ideas of children with autism concerning self and spirituality. Journal of Religion, Disability \& Health, 13, 6476. doi: $10.1080 / 15228960802581446$

Liu, E.X., Carter, E.W., Boehm, T.L., Annandale, N.H., \& Taylor, C.E. (2014). In their own words: The place of faith in the lives of young people with autism and intellectual disability. Intellectual and Developmental Disabilities, 52, 388-404.

doi: 10.1352/1934-9556-52.5.388

Ludewig, A. (2006). Leni Riefenstahl's encounter with the Nuba. Interventions: International Journal of Postcolonial Studies, 8, 83-101. doi: 10.1080/13698010500515191

Malhi, P., \& Singhi, P. (2014). A retrospective study of toddlers with autism spectrum disorder: Clinical and developmental profile. Annals of Indian Academy of Neurology, 17, 25-29. doi: 10.4103/0972-2327.128537

Marker, C., Weeks, M., \& Kraegel, I. (2007). Integrating faith and treatment for children with high functioning autism spectrum disorders. Journal of Psychology and Christianity, 26, 112-121. Retrieved from http://caps.net/membership/publications/jpc Mathisen, B., Carey, L.B., Carey-Sargeant, C.L., Webb, G., Millar, C., \& Krikheli, L. (2015). Religion, spirituality and speech-language pathology: A viewpoint for ensuring patient-centred holistic care. Journal of Religion \& Health, 54, 23092323. doi: 10.1007/s10943-015-0001-1

McCravy, S., Johnson, A., Wetsel, M.A., \& Konz, L. (2010). Speak the language of autism. The Nurse Practitioner, 35, 26-33. doi: 10.1097/01.NPR.0000369939.77975.54 
SPIRITUALITY IN NON-VERBAL AUTISM: A SCOPING REVIEW

McGee, D. (2010). Widening the door of inclusion for children with autism through faith communities. Journal of Religion, Disability \& Health, 14, 279-292. doi: 10.1080/15228961003622351

McGrath, P., \& Newell, C. (2004). The human connection. Journal of Religion, Disability \& Health, 8, 89-103. doi: 10.1300/J095v08n01_07

McIntosh, M. (1998). Mystical theology. Malden, MA: Blackwell.

McMullen, P. (2000). The gifted side of autism. Focus on Autism and other Developmental Disabilities, 15, 239-242. doi: 10.1177/108835760001500414

McNair, J. (2008). The indispensable nature of persons with intellectual disabilities to the Church. Journal of Religion, Disability \& Health, 12, 321-329. doi: 10.1080/15228960802515618

McOmber, A. (2008). A most amazing gift. Dialogue: A Journal of Mormon Thought, 41(4), 191-197. Retrieved from http://www.dialoguejournal.com/

Merrick, J., Morad, M., \& Levy, U. (2001). Spiritual health and persons with intellectual disability. Journal of Religion, Disability \& Health, 5, 113-121. doi: 10.1300/J095v05n02_09

Muller, E., Schuler, A., \& Yates, G. (2008). Social challenges and supports from the perspective of individuals with Asperger syndrome and other autism spectrum disabilities. Autism, 12, 173-190. doi: 10.1177/1362361307086664

Nixon, A.V., Narayanasamy, A., \& Penny, V. (2013). An investigation into the spiritual needs of neuro-oncology patients from a nurse perspective. BMC Nursing, 12(2). doi: $10.1186 / 1472-6955-12-2$

Oner, P., Ozgur, O., \& Munir, K. (2014). Three-item direct observation screen (TIDOS) for autism spectrum disorder. Autism, 18, 733-742. doi: $10.1177 / 1362361313487028$ 
SPIRITUALITY IN NON-VERBAL AUTISM: A SCOPING REVIEW

Parner, E. T., Schnedel, D. E., \& Thorsen, P. (2008). Autism prevalence trends over time in Denmark. Archives of Pediatrics and Adolescent Medicine, 162, 1150-1156. doi: 10.1001/archpedi.162.12.1150

Pasco, G. (2011). The diagnosis and epidemiology of autism. Tizard Learning Disability Review, 16, 5-19. doi: 10.1108/13595471111172813

Persico, A.M., \& Merelli, S. (2014). Environmental factors in the onset of autism spectrum disorder. Current Developmental Disorders Reports, 1, 8-19. doi: 10.1007/s40474-013-0002-2

Peters, R. (2009). Self-advocacy through participation in the Lord's supper for persons who are conceptually non-expressive. Journal of Religion, Disability \& Health, 13, 297310. doi: 10.1080/15228960902931913

Phelps, K., Hodgson, J., McCammon, S., \& Lamson, A. (2009). Caring for an individual with autism disorder: A qualitative analysis. Journal of Intellectual \& Developmental Disability, 34, 27-35. doi: 10.1080/13668250802690930

Poston, D., \& Turnbull, A. (2004). Role of spirituality and religion in family quality of life for families of children with disabilities. Education and Training in Developmental Disabilities, 39, 95-108. Retrieved from http://www.jstor.org/

Reynolds, T.E. (2012). Theology and disability: Changing the conversation. Journal of Religion, Disability \& Health, 16, 33-48. doi: 10.1080/15228967.2012.645612

Rosetti, Z., Ashby, C., Arndt, K., Chadwick, M., \& Kasahara, M. (2008). "I like others to not try to fix me”: Agency, independence, and autism. Intellectual and Developmental Disabilities, 46, 364-375. doi: 10.1352/2008.46:364-375

Rosti, R.O., Sadek, A.A., Vaux, K.K., \& Gleeson, J.G. (2014). The genetic landscape of autism spectrum disorders. Developmental Medicine and Child Neurology, 56, 12-18. doi: 10.1111/dmcn.12278 
SPIRITUALITY IN NON-VERBAL AUTISM: A SCOPING REVIEW

Roth, L. (2013). Autism spectrum disorder (Briefing Paper No. 5/2013). Retrieved from Parliament of New South Wales website: https://www.parliament.nsw.gov.au/ Rudy, L.J. (2015). Autism and spirituality.

Retrieved from http://autism.about.com/od/inspirationideas/a/StillmanQA.htm Russinova, Z., \& Cash, D. (2007). Personal perspectives about the meaning of religion and spirituality among persons with serious mental illnesses. Psychiatric Rehabilitation Journal, 30, 271-284. doi: 10.2975/30.4.2007.271.284

Samuel, G. B. (2009). Autism and mediation: Some reflections. Journal of Religion, Disability \& Health, 13, 85-93. doi: 10.1080/15228960802581487

Sandiford, G.A., Mainess, K.J., \& Daher, N.S. (2013). A pilot study on the efficacy of Melodic Based Communication Therapy for eliciting speech in nonverbal children with autism. Journal of Autism and Developmental Disorders, 43, 1298-1307. doi: 10.1007/s10803-012-1672-z

Schaap-Jonker, H., Sizoo, B., van Schothorst-van Roekel, J., \& Corveleyn, J. (2013). Autism spectrum disorders and the image of God as a core aspect of religiousness. International Journal for the Psychology of Religion, 23, 145-160. doi: 10.1080/10508619.2012.688005

Schieve, L.A., Rice, C., Yeargin-Allsopp, M., Boyle, C.A., Kogan, M.D., Drews, C., \& Devine, O. (2012). Parent-reported prevalence of autism spectrum disorders in USborn children: An assessment of changes within birth cohorts from the 2003 to the 2007 National Survey of Children’s Health. Maternal and Child Health Journal, 16, 151-157. doi: 10.1007/s10995-012-1004-0

Schlosser, R.W., Balandin, S., Hemsley, B., Iacono, T., Probst, P., \& von Tetzcher, S. (2014). Facilitated communication and authorship: A systematic review. Augmentative and Alternative Communication, 30, 359-368. 
SPIRITUALITY IN NON-VERBAL AUTISM: A SCOPING REVIEW

doi: 10.3109/07434618.2014.971490

Selway, D., \& Ashman, A. (1998). Disability, religion and health: A literature review in search of the spiritual dimensions of disability. Disability \& Society, 13, 429-439. doi: 10.1080/09687599826722

Shogren, K., \& Rye, M. (2008). Religion and individuals with intellectual disabilities: An exploratory study of self-reported perspectives. Journal of Religion, Disability \& Health, 9, 29-53. doi: 10.1300/J095v09n01_03

Silence. (2015). In Merriam-Webster's online dictionary. Retrieved from http://www.merriam-webster.com/dictionary/silence

Simmons, D.R., Robertson, A.E., McKay, L.S., Toal, E., McAleer, P., \& Pollick, F.E. (2009). Vision in autism spectrum disorders. Vision Research, 49(22), 2705-2739. doi: 10.1016/j.visres.2009.08.005

Siniscalco, D., Cirillo, A., Bradstreet, J.J., \& Antonucci, N. (2013). Epigenetic findings in autism: New perspectives for therapy. International Journal of Environmental Research and Public Health, 10, 4261-4273. doi: 10.3390/ijerph10094261

Skinner, D., Correa, V., Skinner, M., \& Bailey, D. (2001). Role of religion in the lives of Latino families of young children with developmental delays. American Journal on Mental Retardation, 106, 297-313.

doi: 10.1352/08958017(2001)106<0297:RORITL>2.0.CO;2

Solitude. (2015). In Merriam-Webster's online dictionary. Retrieved from http://www.merriam-webster.com/dictionary/solitude

Speraw, S. (2006). Spiritual experiences of parents and caregivers who have children with disabilities or special needs. Issues in Mental Health Nursing, 27, 213-230. doi: 10.1080/01612840500436974 
SPIRITUALITY IN NON-VERBAL AUTISM: A SCOPING REVIEW

Stillman, W. (2006). Autism and the God connection: Redefining the autistic experience through extraordinary accounts of spiritual giftedness. Naperville, IL: Sourcebooks.

Sunderland, N., Chenoweth, L., Matthews, N., \& Ellem, K. (2015). 1000 voices: Reflective online multimodal narrative inquiry as a research methodology for disability research. Qualitative Social Work, 14, 48-64. doi: 10.1177/1473325014523818

Swanson, S. (2010). Experiential religion: A faith formation process for children with autism. Journal of Religion, Disability \& Health, 14, 238-255.

doi: 10.1080/15228961003622393

Swinton, J. (1997). Restoring the image: Spirituality, faith, and cognitive disability. Journal of Religion, Disability \& Health, 36, 21-28. doi: 10.1023/A:1027484714661

Swinton, J. (2001). Spirituality and mental health care: Discovering a forgotten dimension. London, England: Jessica Kingsley.

Swinton, J. (2011).Who is the God we worship? Theologies of disability; challenges and new possibilities. International Journal of Practical Theology, 14, 273-307. doi: 10.1515/IJPT.2011.020

Swinton, J., Mowat, H., \& Baines, S. (2011). Whose story am I? Redescribing profound intellectual disability in the Kingdom of God. Journal of Religion, Disability \& Health, 15, 5-19. doi: 10.1080/15228967.2011.539337

Swinton, J., \& Trevett, C. (2009). Religion and autism: Initiating an interdisciplinary conversation. Journal of Religion, Disability and Health, 13, 2-6. doi: 10.1080/15228960802606193

Tarakeshwar, N., \& Pargament, K. I. (2001). Religious coping in families of children with autism. Focus on Autism and Other Developmental Disabilities, 16, 247-260. doi: $10.1177 / 108835760101600408$

Travers, J.C., Tincani, M.J., \& Lang, R. (2014). Facilitated communication denies 
SPIRITUALITY IN NON-VERBAL AUTISM: A SCOPING REVIEW

people with disabilities their voice. Research and Practice for Persons with Severe Disabilities, 39, 195-202. doi: 10.1177/1540796914556778

Treloar, L. (2002). Disability, spiritual beliefs and the Church: The experiences of adults with disabilities and family members. Journal of Advanced Nursing, 40, 594-603. doi: 10.1046/j.1365-2648.2002.02417.x

Tsai, L.Y. (2000). I learn about autism from my son and people like him. Focus on Autism and Other Developmental Disabilities, 15, 202-205.

doi: $10.1177 / 108835760001500403$

Turner, S., Hatton, C., Shah, R., Stansfield, J., \& Rahim, N. (2004). Religious expression amongst adults with intellectual disabilities. Journal of Applied Research in Intellectual Disabilities, 17, 161-171. doi: 10.1111/j.1468-3148.2004.00192.x

Visuri, I. (2012). Could everyone talk to God? A case study on Asperger’s syndrome, religion, and spirituality. Journal of Religion, Disability \& Health, 16, 352-378. doi: 10.1080/15228967.2012.731888

Vogel, G., \& Reiter, S. (2003). Spiritual dimensions of Bar/bat Mitzvah ceremonies for Jewish children with developmental disabilities. Education and Training in Developmental Disabilities, 38, 314-322. Retrieved from http://www.jstor.org/

Vogel, J., Polloway, E., \& Smith, D. (2006). Inclusion of people with mental retardation and other developmental disabilities in communities of faith. Mental Retardation, 44, 100-111. doi: 10.1352/0047-6765(2006)44[100:IOPWMR]2.0.CO;2

Waltz, M. (2009). From changelings to crystal children: An examination of 'New Age' ideas about autism. Journal of Religion, Disability \& Health, 13, 114-128. doi: 10.1080/15228960802581511

Watts, G. (2011). Intellectual disability and spiritual development. Journal of Intellectual \& Developmental Disability, 36, 234-241. doi: 10.3109/13668250.2011.617731 
SPIRITUALITY IN NON-VERBAL AUTISM: A SCOPING REVIEW

Webb-Mitchell, B. (2010). Educating toward full inclusion in the body of Christ: People with disabilities being full members of the Church. Journal of Religion, Disability \& Health, 14, 256-268. doi: 10.1080/15228961003622401

Webster, J. (2004). Religious education for children with severe learning difficulties: Constructing a framework, finding a medium, exploring a story. Support for Learning, 19, 119-124. doi: 10.1111/j.0268-2141.2004.00333.x

Weerstra, C. (2011). Special catechism for special kids: Teaching autistic children about God. New York, NY: Schenectady.

Whittaker, C.A. (2012). The speech aversion hypothesis has explanatory power in a minimal speech approach to aloof, non-verbal, severe autism. Medical Hypotheses, 78, 15-22. doi: 10.1016/j.mehy.2011.09.031

Williams, E. (2004). Who really needs a ‘theory’ of mind? An interpretative phenomenological analysis of the autobiographical writings of ten high-functioning individuals with an autism spectrum disorder. Theory \& Psychology, 14, 704-724. doi: $10.1177 / 0959354304046180$

Wilson, C. (2011). Is there a case for community learning disability teams considering the spiritual needs of people with learning disabilities? Tizard Learning Disability Review, 16, 31-40. doi: 10.1108/13595471111158675

World Health Organization. (2013). Autism spectrum disorders \& other developmental disorders. From raising awareness to building capacity (Meeting Report). Retrieved from www.who.int

Young-Pelton, C.A., \& Doty, D. (2013). Improving educational programs for students with autism in rural schools: A preliminary program description of the Montana Autism Education Project. Rural Special Education Quarterly, 32, 24-32. Retrieved from http://www.proquest.com 
Zahorodny, W., Shenouda, J., Howell, S., Scotto Rosato, N., Peng, B., \& Mehta, U. (2014). Increasing autism prevalence in metropolitan New Jersey. Autism, 18, 117126. doi: $10.1177 / 1362361312463977$

Zhang, D., \& Rusch, F. (2005). The role of spirituality in living with disabilities. Journal of Religion, Disability \& Health, 9, 83-98. doi: 10.1300/J095v09n01_06 